\title{
Differing Perceptions? Market Practice and The Evolution of
}

\section{FOREIGN SOVEREIGN IMMUNITY}

\author{
W. Mark C. Weidemaier and Mitu Gulati
}

\begin{abstract}
The 20th century witnessed a transformative, "tectonic" shift in international law, from "absolute" to "restrictive" theories of sovereign immunity. As conventionally understood, however, this dramatic transformation represented only a shift in the default rule. Under absolute immunity, national courts could not hear lawsuits and enforce judgments against a foreign sovereign without its consent. Under restrictive immunity, foreign sovereigns were presumptively not immune when they engaged in commercial acts. We demonstrate that market practices undermine this conventional understanding. Using an extensive, twocentury data set of contracts between foreign governments and private creditors, we show that contracting parties have long treated absolute immunity as akin to a mandatory rule, which they could not reliably change by contract. By contrast, we show that the Foreign Sovereign Immunities Act in the U.S. and the State Immunities Act 1978 in the U.K.- - two statutes largely overlooked by international law scholarship - fundamentally reordered a global market for contracts. We explore why the conventional narrative, which relies on analysis of traditional legal materials, is at such odds with the "law on the ground."
\end{abstract}




\title{
Differing Perceptions? Market Practice and The Evolution of
}

\section{FOREIGN SOVEREIGN IMMUNITY}

\author{
W. Mark C. Weidemaier \& Mitu Gulati*
}

\section{INTRODUCTION}

The law of foreign sovereign immunity changed dramatically over the twentieth century. The starting point was the rule of absolute immunity. Under that rule, a state was immune from suit in another state's courts (jurisdictional immunity) and its assets could not be seized to enforce a court judgment (execution immunity). Over time, this doctrine gave way to the so-called "restrictive" theory of immunity, under which foreign sovereigns were no longer immune in cases arising out of their commercial (as opposed to public, or governmental) acts. The shift from absolute to restrictive immunity is one of the most significant developments in the field of customary international law (Nagan and Root 2013; Verdier and Voeten 2015). It represented a great, "tectonic shift" (Koh 2011, p. 1143) in the willingness of national courts to enforce private claims against foreign governments. But despite its perceived significance, the shift is

\footnotetext{
* Faculty at UNC Chapel Hill Law School and Duke Law School, respectively. For comments and conversations regarding earlier drafts, we thank Curt Bradley, John Coyle, Dave Hansen, Richard Myers, John Orth, Mark Weisburd, and workshop participants at the University of North Carolina School of Law.
} 
conventionally understood only as a change in the default rule. Under absolute immunity, a creditor who wants legal enforcement rights must bargain for them ex ante. Under restrictive immunity, no such bargain is necessary.

The conclusion that sovereign immunity rules are defaults emerged from a methodology commonly employed in studies of customary international law (CIL). Simply defined, CIL is "general practice accepted as law.", In other words, a CIL rule exists if a sufficiently large number of states engage in a practice because they view it as obligatory. To identify state practice with regard to sovereign immunity, tribunals, practitioners, and scholars have examined the law on the books - i.e., the rules as articulated by legislatures, courts, and other government agents (Jennings and Watts 2008; Fox 2008; Whytock 2013; Verdier and Voeten 2015). Traditional scholarship and practice in the field of CIL thus treats official statements of the law_-judicial opinions, statutes, etc. - as the central subject of inquiry.

We adopt a different perspective. Rather than look to the law on the books, we examine the behavior of the actors most directly affected by the rules of foreign sovereign immunity: government debtors and their private creditors. The relationship between formal law and behavior is a central inquiry in sociolegal studies. Among others, Macaulay (1963), Greif (1989), Ellickson (1994), Bernstein (1992), George et al. (2011), and Hadfield and Bozovic (2016), have demonstrated that private actors do not always order their affairs in accordance 
with formal legal rules. Yet mainstream legal analysis often ignores these insights. This is particularly true in the field of CIL, the content of which is drawn almost completely from the law on the books.

In this article, we draw on what is (to our knowledge) the most comprehensive dataset of contracts between private citizens and foreign governments. Our data consist of sovereign bonds - i.e., loan contracts sold by governments to investors in foreign markets. Because sovereign borrowers often defaulted, and because the borrower's own courts would likely prove inhospitable or ineffective, foreign investors had an interest in accessing the courts of their home states, if the law of sovereign immunity would allow this. The dataset includes thousands of contracts and spans two centuries and multiple jurisdictions with different sovereign immunity rules, and we use it to study how loan contracts responded to changes in these rules.

We review the data below, but the principal finding is this: Until the 1970s, virtually no contract, in any jurisdiction we have identified, modified the background rules of sovereign immunity. Then, in the mid- to late-1970s, everything changed. Almost overnight, bonds issued in multiple jurisdictions uniformly adopted detailed clauses bestowing legal enforcement rights on creditors. This shift correlates almost perfectly with two statutory developments: the Foreign Sovereign Immunities Act (FSIA) in the United States (1976) and the State Immunities Act 1978 (SIA) in the United Kingdom. Every prior 
development in the law of sovereign immunity seemingly passed unnoticed. Prominent judicial opinions in major creditor jurisdictions; draft treaties purporting to codify customary international law; official proclamations of national policy by executive branch officials - none appear to have had any impact on contracts. By contrast, the FSIA and SIA had a dramatic and immediate effect on contracting behavior.

This empirical picture is puzzling for two reasons. First, it is at odds with the traditional conception in international law scholarship of sovereign immunity as a default rule. Under absolute immunity, creditors had to explicitly bargain for court access, but they did not do so despite having economic incentives to seek greater legal enforcement rights. Under restrictive immunity, creditors presumptively had access to national courts, yet they bargained for access anyway. Why did express waivers of immunity begin to appear only after the shift to restrictive immunity, when they were no longer as necessary? Second, what explains the suddenness and uniformity of the change in contracting practices? Most scholars of international law describe the transition from absolute to restrictive immunity as a gradual one, taking over a century (e.g., Verdier and Voeten 2015; van Alebeek 2008, p. 151-52; Badr 1984, p. 57-58.) This inclines observers to view statutes like the FSIA as relatively minor developments that did little more than codify existing law (e.g., Badr 1984). In the context of our data, however, the gradual legal transition described by the literature on CIL seems 
largely irrelevant. Why did these two statutes dramatically reshape the contracting landscape?

This article offers preliminary answers to these questions. In the process, it calls into question the understanding of absolute immunity as a default rule.

Contrary to this conventional wisdom, our findings imply that sovereign borrowers and private investors viewed immunity as akin to a mandatory rule. ${ }^{\text {ii }}$ We argue that early case law developments, which commentators interpreted to mean that sovereign immunity could be waived by contract, were in fact tentative and ambiguous commitments that gave investors little assurance that courts would be receptive to their claims. Put another way, these early judicial pronouncements were not interpreted as credible commitments that courts would entertain suits against foreign governments. The FSIA and SIA, by contrast, may have represented the first credible commitments to enforce privately-negotiated waivers of immunity.

Yet there is almost surely more to the story, for not all credible changes in the legal rule dramatically impact behavior on the ground. Thus, after re-casting absolute immunity as akin to a mandatory rule, we turn to the impact of the FSIA and SIA on contract drafting. As we explain, actors in the sovereign debt markets are likely to value new terms only when they believe that others share that view. In consequence, a new contract clause will become widespread only if market actors believe that others will embrace the clause. We argue that the FSIA and 
SIA served as coordinating devices around which the lawyers, bankers, and finance officials developed common expectations about how to prepare sovereign bond documentation (e.g., McAdams 2000).

We close by highlighting the implications of our findings - and our methodology — for scholarship and practice in the field of CIL. As we have noted, the traditional methodology for detecting CIL rules seeks to infer state practice from judicial opinions, legislative acts, executive proclamations, diplomatic acts and protests, and other public statements of the law on the books. This approach raises serious methodological difficulties, not the least of which is that tribunals, lawyers, and legal academics rarely have the resources and disciplinary training to investigate, interpret, and aggregate the law on the books in nearly 200 states (Kelly 2000; Young 2002; Petersen 2009; Choi and Gulati 2015; Scoville 2016). Our findings highlight another, perhaps deeper, flaw. Traditional CIL methodology has few tools for distinguishing law that matters - in the sense of impacting behavior-from law that does not. By shifting our focus to behavior on the ground, we highlight an alternative way to explore the development of CIL rules. Our approach complements traditional CIL methods and can support (or undermine) the conclusions those methods yield.

\section{THE EVOLUTION OF SOVEREIGN IMMUNITY LAW}

This section provides an overview of the evolution of foreign sovereign immunity law. We focus on the law on the books, and on how commentators 
writing at the time understood that law. Put differently, we tell the story that results from application of traditional methods used in the study of CIL. As will become clear when we turn to the data, a different picture emerges from the behavior of actors on the ground. That fact will complicate the story we relate in this section.

Because CIL rules are generalized from the practices of many states, they necessarily obscure differences across jurisdictions (Stephan 2010). To illustrate this, we give detail about the different evolutionary paths taken by the law in the three major financial centers for the issuance of sovereign bonds over the time period we examine (roughly 1810-2010): France, the U.K., and the U.S. The law on the books differed substantially in these jurisdictions, and these differences should, in theory, have produced practices with regard to contract drafting.

\section{The evolution from absolute to restrictive immunity}

Foreign sovereigns traditionally enjoyed absolute immunity from suit and from execution (Verdier and Voeten 2015). The rule was subject to exceptions. For example, national courts could adjudicate questions of ownership over immovable property located in their jurisdiction. As most commentators understood the law, however, a foreign sovereign could not be sued without its consent, and even if it consented to be sued, its assets remained immune from seizure. 
Because it is inferred from state practices in the aggregate, CIL has been called "the generalization of the practice of states" (Fisheries Case (U.K. v. Norway), 1951 I.C.J 116, 191. (J. Read)). Another way to put this is to say that CIL rules are imprecise. To say that a sovereign may consent to suit, for instance, does not indicate whether it may revoke its consent once given. By the late-19th century, at least some courts had indicated that consent was irrevocable. One early French case involved litigation against the Government of Tunis. ${ }^{\text {iii }}$ The relevant bonds were issued through French banks and contained a clause providing that disputes would be adjudicated in France. The Bey of Tunis had established a commission to manage his financial affairs and argued that this divested the French courts of jurisdiction. The Civil Tribunal of the Seine rejected this argument, noting that the stipulation to jurisdiction could not "be nullified by the personal will of one of the parties" (Rochaïd-Dahdah v. Gouvernement tunisien, Tribunal Civil de la Seine, April 10, 1888, 15 ClunEt 670 (1888) (Fr.)). Taken at face value, this appears to be an early, unequivocal articulation of the view that absolute immunity was a presumption that could be trumped by contract.

Writing in the 1930s, Eleanor Wyllys Allen undertook a crossjurisdictional survey of the law of foreign sovereign immunity. She discussed the Tunisian decision and other cases, noting what had become the "usual view" that a sovereign could renounce its immunity by contract (1933, p. 19-20). She preferred the approach taken by English courts, which required the sovereign to 
consent at the time of the suit, but conceded that the law was to the contrary. Others shared this assessment. A contemporaneous proposal to codify the rules of international law on the subject ("the Harvard Project") asserted that a foreign government lost its immunity from suit when it had "previously consented to the institution of such a proceeding." The accompanying comments explained that the rule was "so obviously equitable that its general acceptability may be assumed" (Harvard Research 1932, 549). ${ }^{\text {iv }}$ After canvassing the law of multiple jurisdictions, the authors dismissed English practice as the only exception to the rule.

The rule regarding waiver of execution immunity was less wellestablished. Allen noted rare occasions on which a foreign state was "held to have submitted even to execution against its property," without suggesting that these episodes represented shocking departures from settled law (1933, p. 49, 68). By later in the century, there was additional authority for the proposition that a sovereign could waive execution immunity, as long as it did so expressly. A report prepared in 1949 to inform State Department deliberations on whether to adopt restrictive immunity ("the Snow Report") characterized French law as receptive to such waivers, citing a case from 1938. The general belief, however, was that states probably would not waive their execution immunity. Thus, the authors of the Harvard Project $(1932,707)$ did not propose a rule on the subject. The comments to the proposed convention characterized such a rule as 
"unnecessary" but did not suggest that it would be inappropriate to recognize a waiver of execution immunity if a sovereign had agreed to one.

The exceptions to immunity discussed thus far all involve waiver. Increasingly, however, courts manufactured other exceptions. By the 1950s, these accrued to the point that prominent commentators expressed skepticism that absolute immunity had ever been so widely practiced as to constitute a rule of CIL (Lauterpacht 1951). Courts had begun to distinguish acts jure imperii (i.e., in the sovereign's public or governmental capacity) from those taken jure gestionis (in a private, civil, or commercial capacity). Sovereigns retained their traditional immunity in the former category, but not the latter. This distinction became the backbone of the theory of restrictive immunity. Over the latter half of the twentieth century, states increasingly adopted the restrictive theory (Verdier and Voeten 2015,12$)$. The transition from absolute to restrictive immunity was primarily the work of national courts, although the rules were eventually codified in the U.S. (in the FSIA), the U.K. (in the SIA), and several other countries (Damrosch 2011, p. 1192).

After a country adopted restrictive immunity, a foreign sovereign could be sued for its commercial activities whether or not it consented to the suit. But the boundaries of "commercial" activity were contested. Our data, for example, consist of sovereign bonds. Early statements of the restrictive immunity rule often preserved the sovereign's jurisdictional immunity in cases involving "public debt" 
(e.g., Westlake 1910; Harvard Project 1932). Thus, it remained uncertain whether the switch to restrictive immunity would benefit investors in sovereign bonds. If incurring debt was a governmental rather than a commercial act, a bond investor could sue only if the bond contained (and the court enforced) a waiver of jurisdictional immunity. Moreover, even in jurisdictions that had embraced restrictive immunity with respect to questions of jurisdiction, sovereigns might retain execution immunity with respect to some or all assets. Thus, all creditors of a sovereign—not just those holding claims arising from "public debt"—had reason to prefer contracts that included waivers of execution immunity.

\section{One international "custom," but varied state practice}

As noted, the conventional understanding of the evolution of sovereign immunity law obscures important differences across jurisdictions. Here, we explain how the law evolved in the three most important jurisdictions for the issuance of sovereign debt: France, the U.K., and the U.S.

France: By relatively early in the 19th century, the London Stock Exchange had become the world's primary market for the issuance of sovereign debt (Neal and Davis 2006), with the Paris Bourse playing a secondary role. By the early 1900s, the Paris market had further declined in significance. Still, for another several decades Paris remained an important market for Russia, China, Romania and other borrowers (e.g., Lavelle 2004, 35). During the period in which Paris was an important global market, the French law of sovereign immunity 
appeared to evolve in significant ways. Although a civil law jurisdiction, French courts played the dominant role in this apparent evolution (Dellapenna 1992, 55).

With regard to jurisdictional immunity, we have noted that, in 1888, a French court refused to allow the Bey of Tunis to revoke consent to be sued in French courts. From this case, and a few later ones, Eleanor Wyllys Allen and other authoritative commenters confidently inferred that French law treated contractual waivers of immunity as irrevocable (Allen 1932, 168; Harvard Project 1932, 551-53).

The law developed more slowly with regard to execution immunity. Yet if French law treated jurisdictional immunity as a default rule, it is not clear why it would adopt a different approach to execution immunity. And in fact, early cases implied that a foreign sovereign could waive both immunities. For example, courts took pains to clarify that a generic waiver of immunity would be construed to refer only to immunity from suit — an unnecessary clarification if execution immunity could not be waived at all (e.g., Veuve Caratier-Terrasson c. Direction générale des Chemins de fer d'Alsace-Lorraine (May 5, 1885)). Later commentators agreed. Describing French practice in 1949, the Snow Report unequivocally proclaimed that French courts enforced express contractual waivers of execution immunity, citing only one 1938 case. If that understanding of French law was correct, we would expect to see waivers of one or both types of immunity 
by the first decades of the twentieth century, if not significantly before, in bonds issued in France. (We do not.)

The United Kingdom: The London Stock Exchange was the world's preeminent financial market by the early 19 th century, and sovereign bonds began to be issued in large numbers after around 1820 (Lipson 1985). Most accounts trace the adoption of restrictive immunity to the enactment of the SIA in 1978. Until the SIA, moreover, it was very much in doubt whether a sovereign could irrevocably waive its immunity by contract. As noted, several English cases required the sovereign to consent at the time of the lawsuit, even if it had previously agreed to submit to the jurisdiction of English courts (e.g., Duff Dev. Co. v. Kelantan, [1924] A.C. 797 (H.L.); Kahan v. Pakistan Fed'n, [1951] 2 K.B. 1003, 1012).

The SIA changed these rules. The statute denies immunity from suit in cases where the sovereign has engaged in commercial activity and clarifies that this includes "any loan or other transaction for the provision of finance." This makes a waiver of jurisdictional immunity of little value, for the default rule is that sovereigns may be sued in debt cases. The SIA also authorizes execution against a foreign sovereign's commercial assets (subject to certain conditions). However, a contractual waiver of execution immunity offers additional value by potentially expanding the pool of assets subject to execution. ${ }^{\mathrm{v}}$ 
United States: The story is more complicated in the U.S., which became a major global capital market after World War I. Most accounts trace the adoption of restrictive immunity to 1952 , when the Department of State (in the so-called Tate Letter) announced that it would abandon absolute immunity as a matter of executive branch policy. But the Tate Letter's impact was complicated, and there were other noteworthy developments both before and after 1952. For our purposes, the important point is that pre-FSIA law left unclear whether a sovereign could irrevocably waive jurisdictional immunity, execution immunity, or both. Nevertheless, some prominent commentators, employing traditional methods of identifying state practice, believed that courts would sometimes enforce immunity waivers.

The Tate Letter signaled the formal U.S. embrace of restrictive immunity (Bradley and Helfer 2010; Dellapenna 2011), but it did not clarify the rights of investors in sovereign bonds. For one thing, the Tate Letter addressed only jurisdictional immunity and did not alter background rules concerning execution immunity. The Tate Letter also left unclear whether the issuance of bonds was a commercial activity; that question was not answered until 1992 (Weltover v. Republic of Argentina, 504 U.S. 607 (1992)) If issuing bonds was a public rather than commercial act, foreign governments would remain immune from suit notwithstanding the switch to restrictive immunity. Finally, the Tate Letter did not 
clarify whether a foreign sovereign could irrevocably waive whatever immunities it retained.

These uncertainties were compounded by a quirk of U.S. practice. Although courts initially played a key role in shaping immunity doctrine, by the 1930s the executive branch had assumed primary responsibility for immunity determinations. A foreign state that wanted to claim immunity would often request a suggestion of immunity from the Department of State. If the Department recognized and allowed the suggestion, its decision was effectively final, ending litigation in U.S. courts (Weisburd 1988; White 1999; Bradley and Helfer 2010). But if the Department declined to support the claim to immunity, the court would have to decide the question on its own.

This two-tier system makes it difficult to draw firm conclusions about preFSIA practice with regard to waivers of immunity. The view that U.S. law allowed a sovereign to revoke its waiver (e.g., Ku 2014, p. 43) derives some support from case law (e.g., Beers v. State of Arkansas, 61 U.S. 527 (1857)), and from public assertions by the Department of State. In a 1961 case, Rich v. Naviera Vacuba, the Department asserted that a waiver of immunity "may be revoked at will—at least prior to the time suit is actually brought to enforce the waiver." (Memorandum for the United States [In Opposition to Application for Stay of Mayan Lines, S.A.], 1 I.L.M. 276, 297 (1961)). 
But matters were not so clear, and surveys of international and U.S. practice before and after Rich reached the opposite conclusion. The Snow Report (1949), like the Harvard Project (1932) before it, concluded that a waiver of immunity was enforceable under international law, and neither listed U.S. practice as in conflict with this rule. Early drafts of the Restatement of the Foreign Relations Law of the United States, published in 1958, also asserted that a sovereign could waive immunity "in advance of any enforcement action." Likewise, a policy research study prepared in 1963 for the Department of State (Sweeney 1963) identified the United Kingdom as the only jurisdiction where a sovereign could revoke its consent to be sued. There was, finally, reason to doubt the Department would consistently intervene on behalf of sovereigns that had agreed to waive immunity, as it had in Rich. That intervention was widely viewed as motivated by political rather than legal factors (e.g., Cardozo 1963, 466-67). Indeed, less than a decade later the Department reversed course, acknowledging that it "accept[ed] the principle" that a sovereign could irrevocably waive immunity by contract (Sovereign Immunity Decisions of the Department of State 1977, 1065-66).

Two conclusions emerge from this murky legal landscape. First, it is easy, using traditional methods for identifying state practice, to conclude that U.S. law was receptive to waivers of sovereign immunity by 1950 or 1960 , if not before. A number of prominent commentators made precisely this inference. To be sure, the 
Department of State might take a contrary position in support of a foreign sovereign's claim to immunity, and in that event a court would likely defer to the Department (e.g., Weisburd 1988; Bradley and Helfer 2010). But in other cases, courts would independently decide whether to enforce a waiver of immunity (e.g., In the Matter of the United States of Mexico v. Schmuck, 293 N.Y. 264 (1944); Victory Transport Inc. v. Comisaria General de Abastecimientos y Transportes, 336 F.2d 354 (2d Cir. 1964)). If this is the correct understanding of U.S. practice, a second conclusion follows. Well before the FSIA's enactment in 1976, private creditors had reason to prefer contracts with clauses that expressly waived the sovereign's immunities from jurisdiction and execution. (This assumes creditors had reason to value legal enforcement $—$ a subject we address below.)

Although the FSIA clarified much about the U.S. law of sovereign immunity, it left questions unanswered. The statute codified the restrictive immunity doctrine but left unclear whether sovereign borrowing constituted commercial activity (Weidemaier 2014). To that extent, the FSIA merely restated practice as it had been since the Tate Letter. The statute, however, removed the State Department from the picture by transferring immunity decisions to the courts. The statute also made clear that a foreign sovereign could not revoke its waiver of jurisdictional or execution immunity. As with the SIA in the United Kingdom, the FSIA granted creditors limited execution rights and allowed 
creditors contract for greater rights by negotiating an expansive waiver of execution immunity.

\section{Preliminary hypotheses}

In sum, the law of foreign sovereign immunity followed different evolutionary paths in these three countries. Figure 1 summarizes these paths, focusing on the eras of primary relevance. ${ }^{\mathrm{vi}}$ The figure does not capture all relevant developments, in particular those affecting the sovereign's immunity from execution. Nevertheless, it captures the most pertinent differences in the three countries.

\section{[Insert Figure 1]}

If creditors were attuned to these developments and wanted to add legal sanctions to the enforcement mix, we would expect different contracting practices to have evolved in each jurisdiction. ${ }^{\text {vii }}$ In particular, we can make the following predictions:

1. In France, waivers of jurisdictional immunity should have begun to appear by the late 19th century, and waivers of execution immunity not long thereafter. Bonds issued after the transition to restrictive immunity would continue to include waivers, both to remove uncertainty about whether bond issuance was a commercial act (e.g., Lauterpacht 1951, p. 262) and to make a wider range of assets subject to execution. 
2. In the United Kingdom, as compared to France, waivers of jurisdictional immunity arguably should not appear at all. Pre-SIA law treated these as revocable; by clarifying that government borrowing was a commercial activity, the statute made them unnecessary. Post-SIA, however, a creditor probably would have valued a waiver of execution immunity, which could no longer be revoked and expanded the pool of assets subject to seizure.

3. In the United States, at any point in the 20th century, waivers of jurisdictional and execution immunity might have been enforced in at least some cases, although the likelihood of enforcement increased over time. The FSIA might have diminished their importance slightly, but not by much, since both types of waiver continued to have a purpose even after the statute. By the early 1990s, however, waivers of jurisdictional immunity would no longer serve much function, as it had become clear that sovereigns lacked jurisdictional immunity in cases arising out of bond debt.

These predictions assume that the law on the books impacts the behavior of actors on the ground. On that assumption, our central prediction is that contracting practices should vary both in time and across the key jurisdictions. In the next section, we examine how this prediction holds up against the data.

\section{HOW CONTRACTS RESPONDED}


Contract law scholarship generally pays little attention to how and why contracts change (Richman 2011; Choi et al., 2013). The assumption is that each contract is negotiated from scratch to allocate the transactional surplus. Yet this assumption is incompatible with the experience of practicing lawyers, who typically start with a template and make changes only as necessary to accommodate the present transaction (e.g., Weidemaier et al. 2013). This reality—in which contracts are "sticky" but do change—brings different questions to the fore. One is how legal change impacts the contract template. In our context, the question is especially interesting, for the changes affect the law's relevance more than its content. When legal actors in a country declare that they will treat sovereign immunity as a default rule rather than a mandatory one, they invite private citizens and foreign governments to bring their disputes out of the domain of politics and into the domain of law. Our data offers a window into how contracts responded to this invitation.

\section{The data}

A typical sovereign bond issue includes multiple documents, prepared by the issuing government, the financial institutions that manage the issue, and the lawyers. These include some or all of the following: (1) a contract between the government and its financial intermediaries; (2) a trust indenture, if the bond calls for a trustee to represent bondholders; (3) the bond itself, governing the relationship between the government and its bondholders; and (4) a prospectus or 
other sales document distributed to investors before the bond issue. Sales documents typically describe or reprint the terms that will appear in the bond.

Conceptually, the dataset has two parts, distinguished by date and by our method of data collection. The first part includes bonds issued between roughly 1820 and 1980. Modern electronic databases do not include most of these bonds, nor is there a comprehensive paper archive. Many government borrowers, however, chose to list bonds on a stock exchange, and exchange archives often include the bonds or related sales documents. London was the dominant exchange until around World War I; New York took its place after the war. We visited the archives for the New York Stock Exchange (at the Library of Congress) and the London Stock Exchange (Guildhall) and took digital images of sales documents. This method of collection left gaps. For instance, some bonds were listed only on other exchanges (such as Amsterdam and Paris); others were not listed on any exchange. Important terms also might have appeared in the loan contract between the government and the underwriting banks, most of which have been destroyed or are housed in inaccessible bank archives. Nevertheless, some prominent bank archives are open to researchers. We visited the Rothschild Archives, the JP Morgan archives at the JP Morgan Library and Museum, and the archives for Barings, UBS, and HSBC banks. We also visited other collections of sovereign bonds and sales documents, as well as some collections of personal papers from prominent bankers, at the Harvard Business School library, the 
British Museum, the Origins of Value Museum at Yale University, Cornell University, Duke University, Columbia University and the Museum of Historical Shares and Bonds (Museum Wertpapierwelt).

The second and larger part of the dataset consists of documents gathered from public databases, which provide fairly comprehensive data on sovereign bonds from around 1980. We used Thomson One Banker and Perfect Information. Our data includes 1906 bonds issued between 1822 and the present. ${ }^{\text {viii }}$ Because London and New York were the primary markets for sovereign bonds during this period, most of our bonds come from these markets. However, the dataset also includes bonds issued in the German, French, Dutch, and other markets.

Our dataset spans two primary eras of sovereign bond lending. The first lasted from the early to mid-1800s through the Great Depression. The second began around 1990 and continues today. Between these eras, sovereign bond markets were relatively dormant (Cassis 2006, 192-93). Sovereign borrowing primarily took the form of direct loans from multilateral institutions such as the World Bank or from commercial bank syndicates (Fisch and Gentile 2004, 105455). As Figure 2 shows, the distribution of bonds in our dataset reflects this history. Figure 2 also reveals that, while we have located a substantial number of bonds from the first era of sovereign bond lending, most were issued in the early 1900s. Sovereign bonds from the 1800s are somewhat under-represented.

[Insert Figure 2.] 
We believe this is the most comprehensive dataset of bond terms, but there remain gaps in the data. The most notable relates to the Paris Bourse, which, despite its relative insignificance by the early 20th century, remained a key market for a number of sovereign issuers (Lavelle 2004, p. 35). We gathered data on the Paris market from three sources. First, the British Museum has a large collection of bonds, including many issued in Paris. Second, many bonds were listed on multiple exchanges (e.g., one tranche of the loan in London and another in Paris). Our visits to the NYSE and the LSE captured many such issues, and the bond documentation usually included the terms applicable in all markets. We also either purchased or copied a large number of bonds issued in Paris from specialty shops in the bourse area catering to collectors of old securities. Through these methods, we were able to gather 126 bonds issued by foreign sovereigns in the Paris market. ${ }^{\text {ix }}$ We cannot be sure that the sample is representative of the broader Paris market but, given the consistency of our data, we do not view this as a serious limitation.

\section{The late-1970s shift in the contract template}

Coding encompassed a number of clauses that address legal enforcement. This includes express waivers of jurisdictional immunity or clauses consenting to the jurisdiction of foreign courts. (For simplicity, we refer to these collectively as "waivers" of jurisdictional immunity.) As an example, bonds issued by Finland in 1977 provide: 
Finland will irrevocably waive any immunity from jurisdiction to which it might otherwise be entitled in any action arising out of or based on the Bonds which may be instituted by any holder of a Bond in any State or Federal court in New York City or in any competent court in Finland. ${ }^{\mathrm{x}}$

We also coded for express waivers of execution immunity, ${ }^{\mathrm{xi}}$ and for the a variety of other clauses that remove technical hurdles, such as service of process, that impede creditor litigation against foreign sovereigns.

We find that, virtually without exception, bonds did not waive sovereign immunity or address any other aspect of legal enforcement until the FSIA and SIA had been introduced and enactment was imminent. After enactment, the market turned on a dime. Whereas virtually no bond, in any market, included a waiver of sovereign immunity before the passage of these two domestic statutes, almost every bond issued post-FSIA (in the New York market) or post-SIA (in the English market) waived the issuing government's jurisdictional immunity. Figure 3 depicts this shift across all markets. ${ }^{\text {xii }}$

\section{[Insert Figure 3.]}

With one exception —-five series of bonds issued simultaneously by Malaysia in 1965 - there are no waivers of jurisdictional immunity in our data until 1975. In that year, Norway issued bonds in the New York market with clauses waiving jurisdictional immunity and submitting to the jurisdiction of New 
York courts. By this time, the FSIA was well on its way to enactment. ${ }^{\text {xiii }}$ Waivers of jurisdictional immunity quickly became commonplace in the New York market. A nearly identical transition occurred in the English market beginning in 1977.

An equally dramatic, though less uniform, shift occurred with regard to waivers of execution immunity. In our data, the first government to make such a waiver was Panama, in a 1977 issuance of bonds governed by English law. Thereafter, virtually all bonds issued in the English market included a waiver of the foreign sovereign's execution immunity $(94 \%)$. The transition occurred a bit more slowly in the New York market, where waivers of execution immunity remained rare through the 1980 s. But after 1995, waivers of execution immunity became relatively commonplace $(72.8 \%)$ in bonds governed by New York law. Figure 4 depicts the shift across the entire dataset.

[Insert Figure 4.]

These patterns are hard to square with the conventional understanding of how sovereign immunity law evolved. Again, that understanding treats the switch from absolute to restrictive immunity as a change in the default rule. But if that were so, we would expect waivers of jurisdictional immunity to be common during the era of absolute immunity and less common thereafter (as states increasingly began to view bond issuance as commercial rather than governmental activity). Our data demonstrate the opposite pattern. As for the prevalence of 
clauses waiving execution immunity, we would not necessarily expect the switch to restrictive immunity to have an impact. That is because, even under restrictive immunity, such waivers can expand the range of property subject to execution. But neither would we expect waivers to appear only after the switch to restrictive immunity. And there is another puzzle: As conventionally understood, the FSIA and SIA were relatively minor developments in the evolution of sovereign immunity law. If that is so, why did they have such a dramatic impact on market practice?

Before turning to these questions, we offer four caveats. First, we acknowledge that there are a few reported cases from the 1800 s and early 1900 s that involve bond debt, some arguably involving waivers of sovereign immunity. Indeed, these cases contributed to the views expressed by the authors of the Harvard Project $(1932,551-52)$ and similar efforts to identify international custom regarding sovereign immunity. To take one example, in a 1922 case, a French court asserted jurisdiction over the Department of Antioqua (Columbia) in a case involving bond debt. The report of that case recounts how the government had appointed an individual to represent it in any "judicial controversy or question" arising out of the loan (Crédit Foncier d'Algerie et de Tunisie c. Département d'Antioquia (Trib. civ., Seine, 1922)). Our dataset does not include the bonds at issue in this case, although no similar language appears in any of the bonds we do have. Moreover, even for bonds in our dataset, it is possible that the 
issuing government might renounce its immunity by statute or in some other public act. Although most bonds and their related disclosure documents reprint laws deemed of interest to bondholders, we cannot detect when the disclosure documents omit relevant information.

These exceptions, however, do not materially alter the picture that emerges from our data. The number of reported "waiver" cases involving sovereign bond debt is tiny and must be contrasted with the uniformity of our data. For example, our dataset includes 111 bonds issued before 1940 in the French market. Not one includes a clause appointing someone to represent the issuing government in any litigation relating to the debt. Nor do any include a clause referencing sovereign immunity or agreeing to submit to the jurisdiction of foreign courts. Indeed, we have found no reported case involving such an express waiver of immunity. At most, these reported cases reveal that some bonds issued in the first era of bond lending included language that a court might construe to waive sovereign immunity. These reported cases do not indicate that such clauses were common; indeed, our data suggest that they were very unusual.

A second caveat relates to bilateral or multilateral treaties that include a waiver of sovereign immunity. As a historical matter, there are numerous examples of treaties in which governments agreed to allow a treaty partner's citizens to bring suit in the treaty partner's domestic courts. In the 1930s, for example, the Soviet Union entered bilateral treaties with France, Germany, and 
other countries which allowed investors from these countries to bring suit against the Soviet Union in the courts of the investor's home state (although such treaties rarely encompassed claims arising out of bond debt.) Likewise, throughout the 19th and much of the 20th centuries, countries used the so-called treaty of friendship, commerce, and navigation to procure certain rights for citizens living in other countries (Coyle 2013). These bilateral treaties often addressed the subject of legal enforcement, although typically by giving citizens access to courts in the host state (or, later, arbitration).

This history supports the view that, as a matter of customary international law, sovereign immunity could indeed be waived by treaty. To that extent, the customary narrative about the evolution of sovereign immunity law is on solid footing. But this does not mean that national courts also recognized a waiver of immunity in a contract negotiated by a private creditor. That rule of international law - so readily embraced by the Harvard Project and similar surveys of state practice - is hard to square with our data. And one can see why state practice might distinguish between the two kinds of waiver. Litigation that results from a treaty-based waiver of immunity is not likely to cause serious diplomatic concerns for the court's home state. After all, political actors in that state agreed to the treaty. To recognize contractual waivers of immunity, by contrast, is to give a private creditor the right to haul foreign governments into national courts, 
whatever the impact this might have on diplomatic relations between the court's home state and the foreign sovereign.

Third, there is anecdotal evidence that waivers of sovereign immunity began to appear somewhat earlier in direct loan contracts between governments and commercial banks. Writing in 1967, Georges Delaume provided several examples, one from as early as 1945 (Delaume 1967, 170-72), and asserted without further support that direct loan contracts routinely included such clauses. ${ }^{\text {xiv }}$ If his claim was correct, sovereign immunity waivers may have become commonplace in direct loan documents a bit earlier than in sovereign bonds. ${ }^{\mathrm{xv}} \mathrm{By}$ and large, however, the contracting practices described by Delaume are consistent with our data. In particular, even direct loans did not embrace waivers of sovereign immunity until well after such waivers had ostensibly become enforceable in many of the relevant jurisdictions.

The fourth caveat relates to arbitration. For more than a century, international courts and tribunals have occasionally presided over claims arising from sovereign debt obligations (Waibel 2013). In many of these cases, the tribunal acquired jurisdiction through treaty or executive agreement, rather than because the loan contract provided for arbitration (e.g., Wuerth 2003, p. 26-27 and $\mathrm{n}$.176). But a handful of bonds in our dataset do include clauses providing for arbitration of debt-related disputes. Focusing on the period before 1945, only four of 534 bonds include such an arbitration clause. These bonds, however, share 
certain features with treaty-based waivers of immunity. In particular, the relevant loans involved the participation of other sovereign governments as potential creditors - for example, as guarantors of the loan. In such cases, the evidence suggest that creditor governments were involved in negotiating loan terms. ${ }^{\text {xvi }}$

\section{EXPLORING THE IMPACT OF SOVEREIGN IMMUNITY STATUTES}

With the caveats noted above, our data paint a picture at odds with the stylized hypotheses we set out earlier. Instead of a slow legal evolution — the story of the law on the books - we see a sudden shift in contracting practices. Moreover, although the law of sovereign immunity law developed differently across jurisdictions, contracts do not reflect these differences. To the contrary, most legal developments had no effect on contracts, including early judicial decisions that led Eleanor Wyllys Allen and other commentators to conclude that a sovereign could irrevocably waive its immunity in a contract. By contrast, and measured by the impact on contracts, the FSIA and SIA appear by far the most important developments in the century-plus evolution of sovereign immunity law. In the sections to follow, we explore the implications of these findings.

\section{Absolute immunity as a mandatory rule}

We begin by reconsidering the conventional wisdom that absolute immunity was a default rule. Our data is more consistent with the view that immunity could not be waived, or at least that investors had significant doubt as to the enforceability of contractual waivers of immunity. If that is correct, then it 
would be more accurate to characterize absolute immunity as a mandatory ruleor, at least, an extraordinarily 'sticky' default.

To begin making this case, it may help to consider why an investor contemplating the purchase of foreign government bonds might care about legal enforcement rights. With few exceptions (e.g., Schumacher et al. 2014; Bulow and Rogoff 1989), the economics and political science literature assumes that, even in the modern era, legal enforcement plays little role in the sovereign debt markets (e.g., Panizza et al. 2009). The logic behind this view is that court judgments only matter when backed by threat of asset seizure, but foreign governments can easily keep assets safe within their borders.

We share this skepticism to a degree, but we also think it understates the modern and historic importance of legal enforcement (Weidemaier and Gulati 2015). Market participants and policymakers have long treated legal enforcement as a relevant concern, although not a primary one. For instance, even during the era of absolute immunity, creditors who had not bargained for a waiver of immunity sometimes tried to assert their claims in the courts (Allen 1933, 166). Recall, moreover, that when negotiating treaties, countries often obtained a waiver of immunity to protect their citizens' foreign investments. It is hard to see why they would bother doing so if domestic constituents did not value legal enforcement. It is also hard to explain early efforts to reform the sovereign debt markets, which sometimes emphasized the potentially-disruptive effect of 
litigation. For example, a 1930s initiative sponsored by the League of Nations proposed reforming bond contracts to prevent "too small a number of bondholders from attempting to institute legal proceedings when the common interests of the bondholders are not really involved" (Committee for the Study of International Loans 1939, 33). Such initiatives suggest that legal enforcement is (and was) at least peripherally relevant.

If a creditor wants to sue a foreign government, it will prefer to do so in the courts of its home state. This means, at minimum, that those courts must be willing to deny the sovereign's claim to jurisdictional immunity and to enter a judgment for the amount due. Having obtained such a judgment, the creditor might find its position materially improved even if the sovereign retained execution immunity. The government might pay the judgment voluntarily, or political officials in the creditor's home state might view a court judgment as a basis for diplomatic intervention (Lauterpacht 1951, p. 222). ${ }^{\text {xvii }}$ If the sovereign also loses its execution immunity, the creditor's position will be improved further. To be sure, the creditor is not likely to seize any assets, for the sovereign can shelter them within its borders. To do this, however, the sovereign must forego putting its assets to more productive use. For example, it cannot buy commercial goods or borrow money in a jurisdiction where creditors might seize the goods or the loan proceeds (Schumacher et al. 2014; Cruces and Trebesch 2013; Shleifer 
2003). The cost of these foregone opportunities might induce the sovereign to pay (Weidemaier and Gelpern 2014).

For these reasons, investors may have had an economic incentive to favor loan contracts that enhanced access to legal enforcement. In turn, sovereign borrowers should have been willing to confer such rights the hope of lowering borrowing costs. This is a familiar pattern in which borrowers cede aspects of their sovereignty to provide assurances of repayment. In the 19th and early 20th centuries, for example, many borrowers ceded control over ports and other revenue-collection points to agents appointed by lenders or their home states (Ahmed et al. 2010; Pérez, Jr. and Weissman 2006; Mitchener and Weidenmier 2005a; Mitchener and Weidenmier 2005b). ${ }^{\text {xiii }}$ If investors valued enforcement rights, there is no reason why governments accustomed to onerous contract terms would draw the line at clauses waiving sovereign immunity—if, that is, courts would predictably give such clauses effect.

But our data are more consistent with a world in which courts were reluctant to enforce privately-negotiated immunity waivers until relatively late in the 20th century. To begin with, note that our data represents a form of state practice, albeit one overlooked by traditional CIL methods. We refer to the practice of waiving immunity, or declining to waive immunity, when contracting with private creditor. When sovereigns and their creditors have economic 
incentives to negotiate immunity waivers but do not do so, this implies that they view immunity as non-waivable.

We do not place too much weight on this argument, for there are other plausible interpretations of the data. After all, a state may refuse to waive its immunity but concede that national courts may give effect to a waiver when made. But given the plausible economic benefits of waiving immunity - and the historical fact that loan contracts often required borrowers to relinquish other aspects of sovereignty - the fact that our data includes no waivers leads us to question the conventional wisdom.

Seeking further insight, we reviewed many of the early legal developments that led commentators to treat sovereign immunity as a default rule (e.g., Harvard Project 1932; Allen 1933; Snow 1949). Even a cursory review prompted speculation that these early developments - though of great interest to scholars and policymakers - did little to dispel investor doubts that courts would predictably enforce contractual immunity waivers. Unlike the FSIA and SIA, early inroads into sovereign immunity gave legal actors significant discretion in how to deploy the rules. As a practical matter, this often worked in the favor of preserving a foreign sovereign's claim to immunity. We have already noted one example. During the period when the Department of State was primarily responsible for making immunity determinations in the United States (roughly 
1935-1975), observers believed it to be influenced primarily by foreign policy considerations rather than the law of sovereign immunity (e.g., Leigh 1969). ${ }^{\text {xix }}$

Other jurisdictions offer similar examples. With regard to jurisdictional immunity, for instance, the rule on the European continent was ostensibly clear and unqualified: A foreign sovereign could be sued when it had waived its immunity by contract (Harvard Project 1932; Cohn 1958, 264-65; Delaume 1967, 159-60). Looking more closely at the cases underpinning this rule, however, reveals that courts sometimes hesitated to intervene in lawsuits against foreign governments. For example, a court might embrace a debatable application of contract law to deny effect to a waiver of immunity. One 1920 Czech case dismissed a lawsuit notwithstanding the submission-to-jurisdiction clause in the creditor's contract with the Austrian State Railways. In the court's view, the disruption associated with the dissolution of the Austro-Hungarian monarchy, which coincided with contract formation, meant that railway officials might not have noticed the clause. The case illustrates one of the methodological problems in attempts to identify CIL rules: When trying to infer state practice from judicial opinions, it is tempting to focus on what the court says rather than on what it does. Thus, neither the Harvard Project (1932) nor the Snow Report (1949) allow the Czech case to undermine the conclusion that sovereign immunity waivers were enforceable, although a creditor might have taken a rather different lesson from the case. 
With regard to execution immunity, creditors may have been even more dubious that courts and other official actors would vigorously enforce their rights. As noted, the law on the books was less clear here, but a case could be made that a sovereign could waive execution immunity by the early to mid-twentieth century. Yet creditors had reason to doubt that this would be mirrored in actual practice. Courts often deployed presumptions - such as the presumption that a sovereign's generic waiver of immunity extended only to jurisdictional immunity — that prevented creditors from seizing sovereign assets. (The presumption remains the law today.) To seize sovereign assets, a creditor also had to enlist the participation of other government officials. In some cases, seizure required the express approval of local officials, which was not always forthcoming (Delaume 1967, 205).

This background may help explain the pattern observed in our data. Take the question of why bonds issued to French investors did not include waivers of jurisdictional immunity. Although the law on the books authorized such waivers, creditors may have been skeptical that French courts would reliably assume jurisdiction over lawsuits against foreign governments. Moreover, unless the sovereign's failure to pay a judgment would have reputational or diplomatic repercussions, the creditor would also need to get around the sovereign's execution immunity. Here, French law was less clear, but French courts had demonstrated little interest in facilitating the seizure of foreign government assets 
(Allen 1932, 181-85). Given this reluctance, and the fact that creditors could not have credibly threatened to seize sovereign assets without the assistance of other government officials, it is perhaps unsurprising that contracting practices in France match those in the United Kingdom, where the law on the books treated waivers as irrevocable.

The same may be true of contracts in the U.S. market. By 1952, the U.S. had embraced restrictive immunity with regard to jurisdictional immunity. Even if debt issuance constituted a governmental rather than commercial activity, there was increasing support for the proposition that a sovereign could irrevocably waive both jurisdictional and execution immunity. Yet until 1976, the Department of State was primarily responsible for implementing these rules, and common wisdom was that it based decisions on political rather than legal considerations (Whytock and Chilton 2015). Especially between 1961 and 1970 - the window between the Department's assertion that a sovereign could revoke its waiver of immunity (in Rich) and its subsequent embrace of a contrary rule — creditors may have doubted of the value of legal enforcement. True, prominent legal authorities asserted that U.S. law would not allow revocation of an immunity waiver. But these were even less authoritative statements of the law than in France, where early cases had articulated the rule in the context of an actual dispute.

To be clear, we are not saying that the SIA and FSIA radically improved the position of creditors. As noted elsewhere, the FSIA's practical impact appears 
to have been modest (Weidemaier 2014). If the foregoing analysis is correct, however, the legal landscape prior to the statutes was pervaded with discretion, which legal actors might exploit to avoid becoming embroiled in disputes between foreign governments and private creditors. Indeed, this tendency exists even today. In the past few years, creditors have tried but failed to seize Argentine assets, including diplomatic property, despite a contractual waiver of immunity that seems to permit seizure. Courts have avoided allowing seizure of such sensitive assets by requiring the waiver to refer expressly to the specified assets. ${ }^{\mathrm{xx}}$ Despite such cases, modern law leaves courts significantly less discretion in deciding whether to hear a lawsuit against a foreign sovereign or to enforce the resulting judgment. The SIA withholds jurisdictional immunity in disputes over "the provision of finance" (SIA $\S 3(3)$ ), and the FSIA commands that a waiver of sovereign immunity is to be enforced "notwithstanding any withdrawal of the waiver which the foreign state may purport to effect" (28 U.S.C. $\S \S 1605)$. Both statutes likewise require the enforcement of waivers of execution immunity (SIA $\S 13(3)$; FSIA $\S 1610(a)(1))$. Developments prior to the statutes, in contrast, left courts with ample discretion, which they sometimes deployed to deny creditors access to legal enforcement rights. ${ }^{\mathrm{xxi}}$ By doing so, they undermined the credibility of case-law commitments to enforce waivers of sovereign immunity. 


\section{The FSIA and SIA as coordinating devices}

Even if we are correct thus far, there is certainly more to the story. Almost overnight, market practice shifted from absolute rejection of clauses waiving sovereign immunity to absolute acceptance. The uniformity of this shift requires further explanation. As noted, loan contracts have long required governments to cede aspects of their sovereignty. A common example from the era of absolute immunity involves ceding control over ports and other revenue collection points. But such arrangements, although common, were generally reserved for borrowers without strong reputations for repayment. Submitting to foreign court jurisdiction may be less offensive to sovereignty than ceding physical control of sovereign territory, but it is not a matter of indifference. Creditworthy governments probably could have maintained access to capital markets without agreeing to waive sovereign immunity. After the FSIA and SIA, however, virtually no government refused to provide a waiver.

The rapidity and uniformity of the shift may reflect a fundamental need for coordination in the sovereign debt markets. Like most contracts for tradable securities, sovereign bonds are based on a template, which varies little from transaction to transaction. Standardization facilitates pricing and investment decisions by minimizing the number of variables that might affect a security's value (e.g., Broad v. Rockwell Int'l Corp., 642 F.2d 929, 942-43 (5th Cir. 1981)). Standardization also results from concentration in the market for legal services. In 
a typical sovereign bond deal, both the issuing government and the underwriters retain outside counsel, although the issuer chooses both sets of lawyers (Bradley et al. 2014). Because law firms accumulate expertise about the government's financial and political affairs, governments also tend to forge lasting relationships with their chosen counsel, and a small group of global law firms dominate this market (Bradley et al. 2014).

Market concentration, combined with the tendency for lawyers to rely on existing forms (Gulati and Scott 2013), means that sovereign bonds are based on a handful of templates. Proposals to modify these templates encounter active resistance, often expressed as a concern over pricing implications. For example, government finance officials long resisted the use of clauses designed to facilitate restructuring in the event of financial distress. Many expressed the concern that investors might misinterpret the adoption of such a clause as a signal that the government presented increased default risk (e.g., Gelpern and Gulati 2006). Such concerns would be eased if finance officials could be assured that other governments would also adopt the new clause. In a market-wide, coordinated switch, no government sends an adverse signal by following the herd.

In part, signaling concerns may explain why governments delayed so long in incorporating clauses waiving sovereign immunity. A finance ministry official contemplating adopting such a clause might wonder how an investor would perceive the change. On the one hand, legal enforcement rights should improve 
the investor's position in the event of a default. From that perspective, the clause seems a welcome addition. An investor might accept lower returns in exchange for meaningful enforcement rights. On the other hand, sovereign loans involve significant information asymmetries (Flandreau et al. 2010; Choi et al. 2012; Bradley et al. 2014). The borrowing government has a great deal of informationhidden to investors - about internal political and economic conditions. If it were to adopt an unusual clause bestowing new enforcement rights, investors might assume that the government presents an increased risk of default and demand a premium for holding the debt. Fear of this investor reaction, however unrealistic, might discourage government finance officials from being the first to adopt immunity waivers.

There is another reason why governments might hesitate to adopt waivers of sovereign immunity. Government officials must justify their actions to some constituency. We suspect that finance officials would find it hard to justify revising existing contract templates to reduce the borrower's sovereign prerogatives and submit it to litigation in foreign courts (e.g., Buchheit 2000, 142). Again, however, widespread use of such clauses provides "cover," normalizing the use of a clause that might otherwise be hard to justify. As a working hypothesis, then, we would expect government officials to agree to immunity waivers only if they received assurances that officials for other 
governments would do the same. And in the concentrated sovereign debt legal market, lawyers are well-positioned to provide such assurances.

For these reasons, actors involved in sovereign debt transactions have an interest in coordinating their behavior. Yet there remains the question of why the FSIA and SIA prompted a switch from one coordinated practice (not waiving immunity) to its opposite. On this question, a growing literature on how law can facilitate coordination may offer insight (e.g., McAdams 2015). One way legal rules induce coordination is by influencing expectations about how others will behave. As an example, consider the rule "drive on the right" (e.g., Schelling 1960; McAdams 2000). A third party who expresses this rule can facilitate coordination even if the party has no sanctioning power or claim to legitimacy (McAdams 2000). Simple expression of the rule can enable coordination by creating the expectation that others will follow the rule.

This is not to say that the identity of the party expressing the rule is irrelevant. When the party has authority as a rule-maker, its pronouncements should more effectively guide behavior. The same is true when a party is empowered to impose sanctions for violation of the rule. For these reasons, courts and legislatures may be especially good at facilitating coordination (e.g., Garret and Weingast 1993; McAdams 2005). Some actors are also effective aggregators of information about behavior. When such actors assert a rule, this may prompt observers to update their beliefs about the prevalence of desirability of a behavior. 
For instance, a legislative prohibition on smoking in public may cause observers to update beliefs as to the dangers of second-hand smoke (Dharmapala and McAdams 2003).

Such considerations may explain the impact of the FSIA and SIA. As noted, the statutes removed jurisdictional immunity and provided limited execution rights in cases arising out of a foreign sovereign's commercial activity. ${ }^{\text {xxii }}$ In addition, the statutes unequivocally allowed creditors to contract for more expansive rights. After these changes, a government borrower that wanted to maintain the status quo could not keep using the same contract template, which said nothing about sovereign immunity. New debt would have been subject to the new default rule, meaning the sovereign could expect to be sued if it defaulted in payment, although creditors would have limited execution rights. To approximate the prior status quo, the government would have to contract around the new default rules - for example, by negotiating a clause requiring investors to bring suit exclusively in the borrower's own courts. Governments could, of course, keep using existing contract templates. In that event, investors would have enjoyed the new enforcement rights created by the FSIA and SIA but would also have been subject to the limits those statutes imposed. So why did governments revise the template to bestow additional rights, such as broader rights to execute a judgment against sovereign assets? ${ }^{\text {xxiii }}$ 
If we are correct that the statutes represented the first credible commitments to enforce sovereign immunity waivers, then part of the answer is surely that lawyers had previously seen little point in drafting such clauses. A more complete explanation, however, begins by noting that the statutes made legal enforcement rights especially salient to lawyers (Weidemaier 2014). The FSIA and SIA were prominent topics of discussion and provoked public debate about the rules appropriate for sovereign debt cases (e.g., Delaume 1973). It would have been impossible for the relatively small group of lawyers involved in sovereign bond transactions not to consider the impact of new sovereign immunity rules on bond documentation. And because sovereign immunity waivers were now unequivocally enforceable, it would have been difficult to justify omitting such a clause given the (relatively) creditor-friendly new default rule. Moreover, given the concentrated legal market, lawyers are exceptionally good aggregators of information. This would have allowed them to credibly represent to government finance officials that clauses waiving sovereign immunity were the new market standard, thus mitigating concerns that would normally deter officials from agreeing to such a clause.

To conclude, a number of factors likely explain why the FSIA and SIA had such a dramatic impact on bond contracts. As credible commitments to enforce immunity waivers, the statutes arguably represented a significant change from prior law. By changing the default rule to provide creditors with limited 
enforcement rights, the statutes made it difficult for government borrowers to bargain for a return to the status quo. By increasing the salience of legal enforcement, the statutes made it difficult for lawyers to ignore sovereign immunity when documenting a bond issue. And because of the concentrated nature of this legal market, lawyers were well-positioned to overcome the natural reluctance among finance officials to expose their governments to litigation in foreign courts. Thus, we do not argue that statutory developments necessarily have a more pronounced impact on behavior than judicial developments. We argue only that, in this context, it should not be surprising that the FSIA and SIA had such a dramatic impact on market practice, whereas prior developments had none.

\section{CIL AND THE SEARCH FOR STATE PRACTICE}

In this final section, we return to our starting point: the topic of customary international law, defined as "general practice accepted as law" (ICJ Statute, art. 38). The definition incorporates two elements. The first is state practice. When there is a general and consistent practice of states, these "international behavioral regularities" (Goldsmith and Posner 1999, 1116) can crystallize into a binding legal rule. This occurs, however, only if states view the practice as obligatory (e.g., Guzman 2006). This second element—-the belief that the practice is legally required—is called opinio juris. 
We are particularly interested in the state practice requirement, and especially in the methodological difficulties posed by the need to identify (and aggregate) the practices of nearly 200 states. An extensive body of international law scholarship explores the difficulties posed by the state practice requirement. For instance, CIL rules ostensibly emerge only when state practice is "uniform, extensive, and representative" (International Law Association 2000). Yet this does not mean the practice must be universal (e.g., Brownlie 2008; Trimble 1986). Indeed, CIL rules can arise even if affected states sometimes act inconsistently with the purported rule. This begs the question of how much inconsistency will be tolerated, and here opinions diverge (e.g., Guzman 2006). Similar uncertainty plagues the question of how much time must pass before state practice crystallizes into CIL (e.g., D'Amato 1971).

These and other doctrinal uncertainties have prompted criticism of CIL (e.g., D’Amato 1968; Trimble 1986; Goldsmith and Posner 1999; Kelly 2000). But despite its critics, CIL remains a vital source of international law, one that binds even dissenting states in most cases. ${ }^{\text {xxiv }}$ And the state practice element- - to which our project speaks most directly—remains a central component of CIL analysis. Because CIL rules develop from state practice, students and practitioners of international law must learn how to identify the practices that matter.

Most lists of relevant practices include national legislation, decisions of international and national tribunals, executive orders, diplomatic correspondence, 
opinions by official legal advisors, and treaty commitments (e.g., Verdier and Voeten 2015; Kelly 2000). Reaching beyond these core state practices, a more inclusive list might include:

diplomatic correspondence, policy statements, press releases, the opinions of government legal advisers, official manuals on legal questions (e.g. manuals of military law), executive decisions and practices, orders to military forces (e.g. rules of engagement), comments by governments on ILC drafts and accompanying commentary, legislation, international and national judicial decisions, recitals in treaties and other international instruments (especially when in 'all states' form), an extensive pattern of treaties in the same terms, the practice of international organs, and resolutions relating to legal questions in UN organs, notably the General Assembly (Brownlie 2008, 24).

It should go without saying that this inquiry raises potent methodological difficulties. As Guzman $(2006,126)$ puts it:

[I]t is fantastical to think that lawyers in a case, much less adjudicators deciding a case or policymakers selecting a course of action, can canvass the virtually infinite universe of potential evidence, let alone come to some understanding of the extent to which a practice has been followed. 
Such criticisms imply a danger inherent in the state practice requirement: Without the ability (and perhaps the inclination) to identify state practices, there a risk that international tribunals and scholars will allow normative preferences to trump actual state assent (e.g., Weisburd 2015).

Our project lends some credence to this skeptical view, under which international tribunals and scholars cannot or will not comb through all relevant evidence of state practice. Indeed, one implication of our findings is that matters may be worse than they seem. Even critics of the state practice requirement largely focus on traditional legal materials - i.e., formal statements of the law by authorized government agents. It is true that such materials provide important evidence of state practice. But it is also true that the law on the books can paint an incomplete, and even misleading, picture, however extensively researchers canvass it.

This paper has focused on a particular example of state practice: that of giving effect to a waiver of sovereign immunity in a private creditor's contract with a foreign government. By reading cases and other traditional legal materials, prominent authorities writing in the early and mid-1900s concluded that the general practice was to enforce such waivers, with the United Kingdom as perhaps the only clear exception. They apparently did not think to ask whether these judicial developments represented credible commitments to respect immunity waivers in the future. This is not because the question is unimportant. 
As a doctrinal matter, it is clear that "cheap talk" merits little weight in the state practice inquiry (e.g., International Law Association 2000, 13-14). The problem is that one must look beyond the law on the books to distinguish credible from noncredible assertions of state practice.

Having made such an inquiry, we are skeptical of the view that sovereign immunity was a default rule until the latter part of the twentieth century. Of course, we do not deny the existence of judicial opinions declaring that sovereign immunity could be waived. We argue only that investor and governments likely viewed these as outlier cases that did not create a legal regime in which waivers would predictably be enforced. With regard to French law, for example, recall that not one of the bonds in our sample included a waiver of immunity despite the ostensibly clear rule giving effect to such clauses. This implies that investors had serious doubts that French courts would enforce immunity waivers. The historical evidence indicates that investors were more than willing to use the courts during the period of absolute immunity, if the courts was willing to take the case. So the answer does not seem to be that investors were indifferent to legal enforcement. The competing explanation - that investors interpreted French courts as reluctant to assume jurisdiction over foreign sovereigns - suggests that legal experts may have assigned too much significance to the early French cases.

The point is that even the most diligent inquiry into state practice will be incomplete if it considers only traditional legal materials. When considering 
whether a judicial opinion, statute, or other formal statement of the law establishes state practice, it is appropriate to ask whether directly affected parties change their behavior in response. If this does not happen, we do not suggest that the statement must automatically be dismissed as cheap talk. (After all, a key insight in socio-legal studies is that parties do not always structure their affairs around the law on the books.) Nevertheless, the red flag is up. When a government agent's act has no effect on behavior, this cautions against assigning the act significant weight as evidence of state practice.

A pessimistic response to our argument is to say that we propose to make the state practice requirement entirely unworkable. If CIL scholarship and practice already fails to take adequate account of the law on the books, what hope is there that jurists and scholars will undertake extensive empirical studies of market practice? But we do not suggest that international tribunals should (or could) commission multiple empirical studies before ruling on contested matters. Instead, we advocate only for a more skeptical conception of the law on the books - one that treats official proclamations of the law as hypotheses about state practice, which should be tested by looking to other evidence when it is available. In a sense, then, we call only for a more robustly empirical conception of customary international law (e.g., Shaffer and Ginsburg 2012).

A more robust conception of state practice, one that takes into account a wider range of empirical evidence, will not always yield easy answers. Indeed, 
such an approach will often complicate traditional conceptions of CIL rules. In a sense, then, one risk of expanding the focus beyond traditional legal materials is that this will reveal the limits of the very concept of state "practice." We have little doubt that detailed empirical examination will often reveal state practices to vary in credibility, consistency, and generality. Where it exists, such variance makes the notion of state practice little more than an intellectual construct.

In other cases, however, a more robust empirical approach to identifying state practice will clarify rather than complicate the law on the books. Previously, for example, we discussed the uncertainty over whether pre-FSIA law in the U.S. treated waivers of sovereign immunity as irrevocable. Our inquiry into government bonds can help resolve this uncertainty. Recall that virtually all preFSIA government bonds issued in the U.S. market omitted waivers of immunity. Because investors had reason to value the option to sue a sovereign that did not pay its debts, the likely explanation is that investors doubted the willingness of U.S. courts (and the Department of State) to enforce such clauses.

Another benefit of looking beyond traditional legal materials is that such an inquiry can help assess the relative significance of legal developments. Recall that conventional wisdom about the evolution of sovereign immunity law assigns relatively little significance to the FSIA and SIA. Yet when these statutes are judged by their impact on market practice, our data reveal them to be the most significant legal developments in the two-century history of the sovereign debt 
markets. The statutes transformed a global market and prompted market participants, for the first time, to incorporate legal enforcement rights into the contract template. By focusing only on the law on the books, traditional analyses have completely overlooked this radical transformation.

\section{CONCLUSION}

We began this project after noting a disjuncture in how our academic colleagues in the field of international law and our practitioner colleagues in the field of international finance understand the law of sovereign immunity. Most international law scholars describe a gradual, century-plus transition between two default rules. They understand sovereign immunity as a default rule and the absolute immunity regime as a baseline presumption of immunity that could be trumped by contract. By contrast, the practitioners appear to understand legal enforcement as a modern development, something that became possible only in the latter part of the 20th century.

As scholars who study the design and evolution of contracts, we believe that market practices can shed light on this disagreement. If contracts are drafted in the shadow of legal rules, then these conflicting understandings of sovereign immunity law imply different predictions about contract design. If the law gradually shifted between default rules - from a presumption of immunity to a presumption of non-immunity - then waivers of immunity should have been fairly common during the era of absolute immunity, when a creditor who had not 
obtained such a waiver would have no legal recourse. By contrast, if legal enforcement did not become relevant until late in the 20th century, then contracts drafted earlier in the century should largely ignore the subject.

Our data largely support the practitioner view and imply that market participants viewed sovereign immunity as akin to a mandatory rule for much of the century. But the dramatic shift in contracting practices prompted by the FSIA and SIA calls for further explanation, as we can think of few legal changes that have had such a transformative impact on contract design. When market participants have strong incentives to coordinate, salient statutory enactments may shape behavior far more than other developments in the law.

\section{REFERENCES}

Aguiar, Mark and Manuel Amador. 2014. "Sovereign Debt." Handbook of International Economics 4: 647-87.

Ahmed, Faisal Z., Laura Alfaro, and Noel Maurer. 2010. "Lawsuits and Empire:

On the Enforcement of Sovereign Debt in Latin America." Law \& Contemporary Problems 73 (4): 39-46.

Allen, Eleanor Wyllys. 1933. The Position of Foreign States Before National Courts, Chiefly in Continental Europe. New York: The Macmillan Co. American Law Institute. 1958. Tentative Draft No. 2, Restatement of the Foreign Relations Law of the United States. 
Badr, Gamal Moursi. 1984. State Immunity: An Analytical and Prognostic View.

The Hague and Boston: Martinus Nijhoff.

Bernstein, Lisa. 1992. "Opting out of the Legal System: Extralegal Contractual Relations in the Diamond Industry.” Journal of Legal Studies 21 (1): 11557.

Bradley, Curtis A. and Laurence R. Helfer 2010. "International Law and the U.S. Common Law of Foreign Official Immunity." The Supreme Court Review: $213-74$

Bradley, Michael, Irving De Lira Salvatierra, and Mitu Gulati. 2014. "Lawyers: Gatekeepers of the Sovereign Debt Market?" International Review of Law and Economics 38 (supplement): 150-68.

Buchheit, Lee C. 2000. How to Negotiate Eurocurrency Loan Agreements (2d ed.). London: Euromoney Publications.

Bulow, Jeremy and Kenneth Rogoff. 1989. "A Constant Recontracting Model of Sovereign Debt." Journal of Political Economy 97 (1): 155-78.

Cardozo, Michael H. 1963. "Judicial Deference to State Department Suggestions: Recognition of Prerogative or Abdication to Usurper?" Cornell Law Quarterly 48 (3):461-98.

Cassis, Youssef. 2006. Capitals of Capital: A History of International Financial Centres, 1780-2005. Cambridge: Cambridge University Press. 
Choi, Stephen J. and Mitu Gulati. 2015. Customary International Law: How Do Courts Do It?, http://papers.ssrn.com/sol3/papers.cfm?abstract id=2561900.

—_, Mitu Gulati, and Eric A. Posner. 2013. "The Dynamics of Contract Evolution." New York University Law Review 88 (1): 1-50.

—, Mitu Gulati, and Eric A. Posner. 2012. "The Evolution of Contractual Terms in Sovereign Bonds." Journal of Legal Analysis 4 (1): 131-79.

Cohn, E.J. 1958. "Waiver of Immunity.” British Yearbook of International Law $34: 260-73$.

Coyle, John F. 2013. "The Treaty of Friendship, Commerce, and Navigation in the Modern Era." Columbia Journal of Transnational Law 51 (2):302-59. - 2015. "The Case for Writing International Law into the U.S. Code." Boston College Law Review 56 (2): 433-92.

Crawford, James. 2008. Brownlie's Principles of Public International Law (8th ed.). Oxford: Oxford University Press.

Cruces, Juan J. and Christoph Trebesch. 2013. "Sovereign Defaults: The Price of Haircuts." American Economic Journal: Macroeconomics 5 (3):85-117. D'Amato, Anthony. 1971. The Concept of Custom in International Law. Ithaca, NY: Cornell University Press. 
Damrosch, Lori F. 2011. "Changing the International Law of Sovereign Immunity Through National Decisions." Vanderbilt Journal of Transnational Law 44 (5):1185-1200.

Delaume, Georges. 1967. Legal Aspects of International Lending and Economic Development Financing. New York: Oceana Publications.

— 1973. "Public Debt and Sovereign Immunity: Some Considerations Pertinent to S.566." The American Journal of International Law 67 (4):745-56.

Dellapenna, Joseph W. 1992. “Foreign State Immunity in Europe.” New York International Law Review 5: 51-62.

—. 2011. "Interpreting the Foreign Sovereign Immunities Act: Reading or Construing the Text?" Lewis and Clark Law Review 55 (3):555-88.

Dharmapala, Dhammika and Richard H. McAdams. 2003. "The Condorcet Jury Theorem and the Expressive Function of Law: A Theory of Informative Law." American Law and Economics Review 5 (1):1-31.

Ellickson, Robert. 1994. Order Without Law: How Neighbors Settle Disputes. Cambridge, MA: Harvard University Press.

Fisch, Jill E. and Caroline M. Gentile. 2004. "Vultures or Vanguards: The Role of Litigation in Sovereign Debt Restructuring." Emory Law Journal 53 (Special Edition): 1043-1114. 
Fox, Hazel. 2008. The Law of State Immunity 2d ed. Oxford: Oxford University Press.

Flandreau, Marc, Juan H. Flores, Norbert Gaillard, and Sebastián Nieto-Parra. 2010. "The End of Gatekeeping: Underwriters and the Quality of Sovereign Bond Markets, 1815-2007.” NBER Working Paper No. 15128. Garrett, Geoffrey and Barry R. Weingast. 1993. "Ideas, Interests, and Institutions: Constructing the European Community's Internal Market." In Ideas and Foreign Policy: Beliefs, Institutions, and Political Change, edited by Judith Goldstein and Robert O. Keohane, 173-206. Ithaca, NY: Cornell University Press.

Gelpern, Anna, and Mitu G. Gulati. 2006. "Public Symbol in Private Contract: A Case Study." Washington University Law Review 84 (7): 1627-715.

George, Tracey E., Mitu Gulati, and Ann C. McGinley. 2011. “The New Old Legal Realism.” Northwestern University Law Review 105 (2): 689-736. Goldsmith, Jack L. and Eric A. Posner. 1999. "A Theory of Customary International Law." University of Chicago Law Review 66 (4): 1113-78. Greif, Avner. 1989. "Reputation and Coalitions in Medieval Trade: Evidence on the Maghribi Traders." The Journal of Economic History 49 (4):857-82. Gulati, Mitu and Robert E. Scott. 2013. The Three and a Half Minute Transaction: Boilerplate and the Limits of Contract Design. Chicago: University of Chicago Press. 
Guzman, Andrew T. 2005. “Saving Customary International Law.” Michigan Journal of International Law 27 (1):115-76.

Hadfield, Gillian and Ivan Bozovic. 2016. "Scaffolding: Using Formal Contracts to Build Informal Relations in Support of Innovation.” USC Law Legal Studies Working Paper No. 12-6 (Feb. 25 draft), http://papers.ssrn.com/sol3/papers.cfm?abstract id=1984915.

Harvard Research in International Law. 1932. "Competence of Courts in Regard to Foreign States." American Journal of International Law Supplement 26 $451-738$.

International Law Association. 2000. Final Report of the Committee on Formation of Customary (General) International Law.

Jennings, Sir Robert and Sir Arthur Watts. 1996. Oppenheim's International Law. Oxford: Oxford University Press.

Kelly, J. Patrick. 2000. "The Twilight of Customary International Law." Virginia Journal of International Law 40 (2):449-544.

Koh, Harold Hongju. 2011. "Foreign Official Immunity After Samantar: A United States Government Perspective." Vanderbilt Journal of Transnational Law 44 (5): 1141-62.

Ku, Julian. 2014. “Don't Cry for Sovereign Debtors: Why Argentina's Defeat in U.S. Courts Does Not Justify a Sovereign Debt Treaty." University of Pennsylvania Journal of International Law 36 (2):433-57. 
Lavelle, Kathryn C. 2004. The Politics of Equity Finance in Emerging Markets. Oxford: Oxford University Press.

Lauterpacht, Hersch. 1951. "The Problem of Jurisdictional Immunities of Foreign States." British Yearbook of International Law 28:220-72.

League of Nations. 1939. Report of the Committee for the Study of International Loans.

Leigh, Monroe. 1969. "New Departures in the Law of Sovereign Immunity." American Society of International Law Proceedings 63 (Fourth Session): 187-92.

Lipson, Charles. 1985. Standing Guard: Protecting Foreign Capital in the 19th and 20th Centuries. Berkeley, CA: University of California Press.

Macaulay, Stewart. 1963. "Non-Contractual Relations in Business: A Preliminary Study." American Sociological Review 28 (1):55-67.

Maurer, Noel. 2013. The Empire Trap: The Rise and Fall of U.S. Intervention to Protect American Property Overseas, 1893-2013. Princeton, NJ: Princeton University Press.

McAdams, Richard H. 2000. “A Focal Point Theory of Expressive Law.” Virginia Law Review 86 (8):1649-1729. . 2005. "The Expressive Power of Adjudication.” University of Illinois Law Review 2005 (5):1043-1122. 
- 2015. The Expressive Powers of Law: Theories and Limits. Cambridge, MA: Harvard University Press.

Mitchener, Kris, and Marc Weidenmier. 2005a. "Empire, Public Goods, and the Roosevelt Corollary." Journal of Economic History 65 (3): 658-92.

—. 2005b. "Supersanctions and Sovereign Debt Repayment." National Bureau of Economic Research Working Paper \#11472, http://www.nber.org/papers/w11472.

Myers, Margaret G. 1945. “The League Loans.” Political Science Quarterly 60 (4): 492-526.

Nagan, Winston P. and Joshua L. Root. 2013. “The Emerging Restrictions on Sovereign Immunity: Peremptory Norms of International Law, the U.N. Charter and the Application of Modern Communications Theory." North Carolina Journal of International Law and Commercial Regulation 38 (2): $375-472$.

Neal, Larry and Lance Davis. 2006. "The Evolution of the Structure and Performance of the London Stock Exchange in the First Global Financial Market, 1812-1914." European Review of Economic History 10 (3):279300.

Panizza, Ugo, Federico Sturzenegger, and Jeromin Zettelmeyer. 2009. "The Economics and Law of Sovereign Debt and Default." Journal of Economic Literature 47: 651-98. 
Pérez, Jr., Louis A., and Deborah M. Weissman. 2007. "Public Power and Private Purpose: Odious Debt and the Political Economy of Hegemony." North Carolina Journal of International Law and Commercial Regulation 32 (4): 699-748.

Petersen, Niels. 2009. "Rational Choice or Deliberation? Customary International Law Between Coordination and Constitutionalization." Journal of Institutional and Theoretical Economics 165 (1):71-85.

Richman, Barak. 2011. “Contracts Meet Henry Ford.” Hofstra Law Review 40 (1):77-86.

Rosenberg, Emily S. 1999. Financial Missionaries to the World: The Politics and Culture of Dollar Diplomacy, 1900-1930. Cambridge, MA: Harvard University Press.

Schelling, Thomas C. 1960. The Strategy of Conflict. Cambridge, MA: Harvard University Press.

Shleifer, Andrei. 2003. "Will the Sovereign Debt Market Survive?” The American Economic Review 93 (2):85-90.

Schumacher, Julian, Christoph Trebesch and Hendrik Enderlein, "Sovereign Defaults in Court: The Rise of Creditor. Litigation 1976-2010”,University of Munich (Economics) Working Paper (December 2014 draft).

Scoville, Ryan. 2016. "Finding Custom." Iowa Law Review (forthcoming). 
Shaffer, Gregory and Tom Ginsburg. 2012. "The Empirical Turn in International Legal Scholarship." The American Journal of International Law 106 (1):146.

Snow, Conrad E. 1949. The Law of Sovereign Immunity. Washington, DC: United States Department of State, Office of the Legal Advisor.

United States Department of State. 1970. Letter Requesting Suggestion of Immunity in the "Caribbean Maritime" Case. In Digest of United States Practice in International Law, edited by Michael Sandler, Detlev F. Vagts, and Bruno A. Ristau, 5 (Appendix):1065-66.

Stephan, Paul B. 2010. “Disaggregating Customary International Law.” Duke Journal of Comparative and International Law 21 (1):191-205.

Sweeney, Joseph M. 1963. The International Law of Sovereign Immunity. Policy Research Study for the Bureau of Intelligence and Research, United States Department of State.

Trimble, Phillip R. 1986. “A Revisionist View of Customary International Law.” UCLA Law Review 33 (3):665-732.

van Alebeek, Rosanne. 2008. The Immunity of States and Their Officials in International Criminal Law and International Human Rights Law. Oxford: Oxford University Press. 
Verdier, Pierre-Hugues and Erik Voeten. 2015. "How Does Customary International Law Change? The Case of State Immunity." International Studies Quarterly 59 (2): 209-22.

Waibel, Michael. 2013. Sovereign Defaults Before Courts and International Tribunals. Cambridge: Cambridge University Press.

Weidemaier, W. Mark C. 2014. "Sovereign Immunity and Sovereign Debt." University of Illinois Law Review 2014 (1): 67-114.

— Hunt for Pari Passu." Law and Social Inquiry 38 (1):72-105. and Anna Gelpern. 2014. "Injunctions in Sovereign Debt Litigation.” 31 (1):189-218. and Mitu Gulati. 2015. "The Relevance of Law to Sovereign Debt." Annual Review of Law and Social Science 11:395-408.

Weisburd, Arthur M. 1988. "Customary International Law: The Problem of Treaties." Vanderbilt Journal of Transnational Law 21 (1):1-46.

- 2015. Failings of the International Court of Justice. Oxford: Oxford University Press.

Westlake, John. 1910. International Law. Cambridge: Cambridge University Press.

White, G. Edward. 1999. "The Transformation of the Constitutional Regime of Foreign Relations.” Virginia Law Review 85 (1):1-150. 
Whytock, Christopher A. 2013. "Foreign State Immunity and the Right to Court Access.” Boston University Law Review 93 (6):2033-94. and Adam S. Chilton. 2015. "Foreign Sovereign Immunity and Comparative Institutional Competence." University of Pennsylvania Law Review 163 (2):411-86.

Wood, Philip R. 2010. "Essay: Sovereign Syndicated Bank Credits in the 1970s." Law and Contemporary Problems 73 (4):7-28.

Wuerth, Ingrid B. 2003. "The Dangers of Deference: International Claim Settlement by the President." Harvard International Law Journal 44 (1):164.

Young, Ernest A. 2002. "Sorting Out the Debate Over Customary International Law." Virginia Journal of International Law 42 (2):365-512.

\section{CASES CITED}

Beers v. State of Arkansas, 61 U.S. 527 (1857).

Broad v. Rockwell Int'l Corp., 642 F.2d 929 (5th Cir. 1981).

Crédit Foncier d'Algerie et de Tunisie c. Département d'Antioquia (Trib. civ., Seine, 1922).

Duff Dev. Co. v. Kelantan, [1924] A.C. 797 (H.L.).

Fisheries Case (U.K. v. Norway), 1951 I.C.J 116, 191. (dissenting opinion of J. Read).

Kahan v. Pakistan Fed'n, [1951] 2 K.B. 1003. 
In the Matter of the United States of Mexico v. Schmuck, 293 N.Y. 264 (1944). Rich v. Naviera Vacuba, Memorandum for the United States [In Opposition to Application for Stay of Mayan Lines, S.A.]. 1961. International Legal Materials 1:295-99.

Rochaïd-Dahdah v. Gouvernement tunisien, Tribunal Civil de la Seine, April 10, 1888. In 15 Clunet 670 (1888).

Société NML Capital Ltd. v. Republique Argentine, Cour de Cassation (1ère Chambre Civile), No. 09-72.057 (Sept. 28, 2011).

Société NML Capital (Iles Caïmans) v. Etat d'Argentine, Cour de Cassation (1ère Chambre Civile), No. 10-25.938, 11-10.450 and 11-13.323 (Mar. 28, 2013)).

Veuve Caratier-Terrasson c. Direction générale des Chemins de fer d'AlsaceLorraine, Cour de Cassation, May 5, 1885. In M. Dalloz, Jurisprudence Générale 341 (1885).

Victory Transport Inc. v. Comisaria General de Abastecimientos y Transportes, 336 F.2d 354 (2d Cir. 1964).

Weltover v. Republic of Argentina, 504 U.S. 607 (1992).

\section{STATUTES CITED}

Foreign Sovereign Immunities Act, 28 U.S.C. 1602 et seq.

State Immunity Act 1978, Ch. 33.

Statute of the International Court of Justice, Art. 38. 


\section{Figure 1.}

1888-1929

\begin{tabular}{|c|c|}
\hline France & $\begin{array}{l}\text { - Absolute immunity } \\
\text { - Waivers of jurisdictional and } \\
\text { (perhaps) execution immunity } \\
\text { irrevocable }\end{array}$ \\
\hline $\begin{array}{r}\text { United } \\
\text { Kingdom }\end{array}$ & $\begin{array}{ll}\text { - } & \text { Absolute immunity } \\
\text { - } & \text { Immunity waiver revocable }\end{array}$ \\
\hline $\begin{array}{r}\text { United } \\
\text { States }\end{array}$ & $\begin{array}{ll}\text { - } & \text { Absolute immunity } \\
\text { - } & \text { Unclear if waiver revocable }\end{array}$ \\
\hline
\end{tabular}

1929-1952

$\begin{array}{ll}\text { - } & \text { Restrictive immunity } \\ \text { - } & \text { Contractual waivers } \\ \text { irrevocable, still valuable }\end{array}$

\begin{tabular}{|ll|}
\hline - & Absolute immunity \\
& \\
\hline \hline - & Absolute immunity waiver revocable \\
\hline & Unclear if waiver revocable \\
\hline
\end{tabular}

$1952-1976$ (1978 in UK)

\begin{tabular}{|c|}
\hline $\begin{array}{l}\text { - } \\
\text { - }\end{array}$ \\
\hline
\end{tabular}

- Absolute immunity

- Immunity waiver revocable

Restrictive immunity for jurisdiction only

- State Department decides most cases

- Increasingly likely that waiver is not revocable
Post-1976 (U.S.)/1978 (U.K.)

$\begin{array}{ll}\text { - } & \text { Restrictive immunity } \\ \text { enforceable, still valuable } \\ \text { enforal waivers }\end{array}$

- Restrictive immunity

- Contractual waivers irrevocable but primarily relevant to execution

- Restrictive immunity

- Courts decide immunity

- Contractual waivers irrevocable, still offer value on both jurisdiction and execution 


\section{Figure 2. Total bonds in data set, by year}

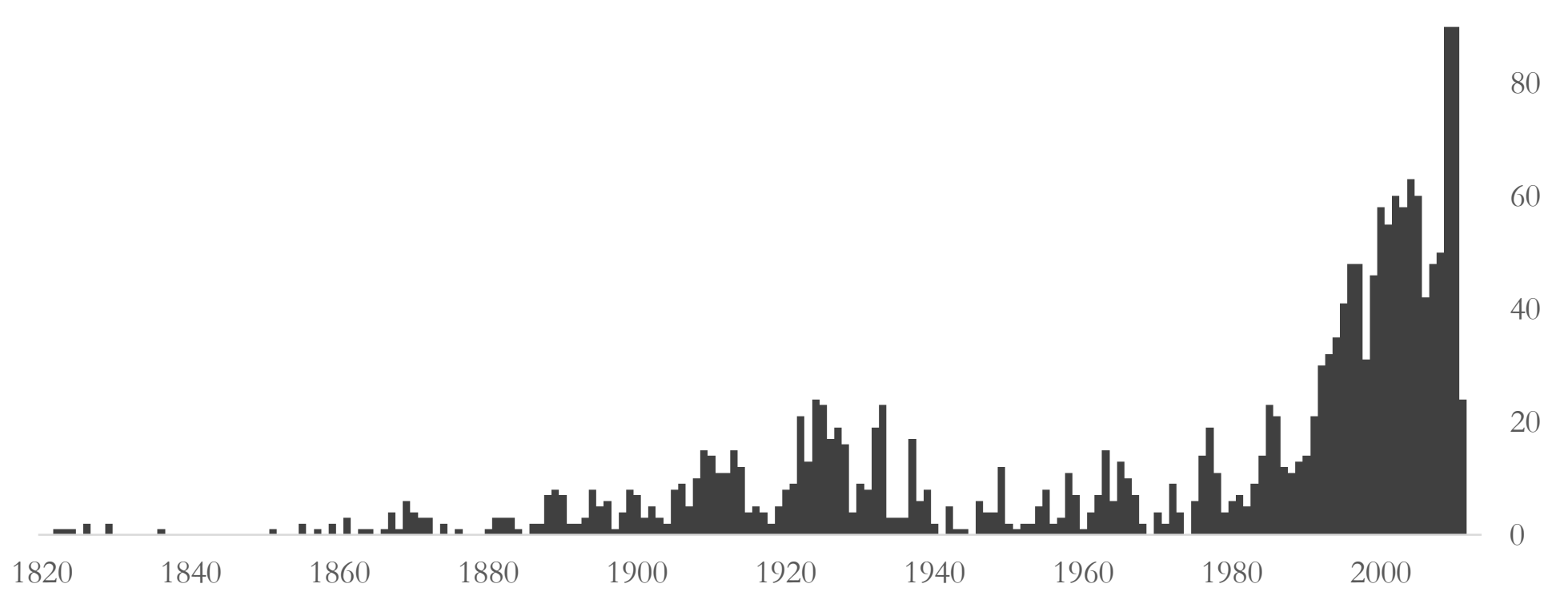




\section{Figure 3. Jurisdictional immunity waivers, all markets (1850-present)}

No waiver of jurisdictional immunity

- Includes waiver 


\section{Figure 4. Execution immunity}

waivers, all markets (1850-present)

No waiver of execution immunity

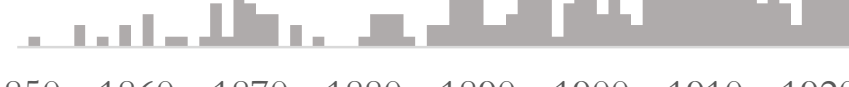


${ }^{\text {i }}$ Statute of the Int'1 Court of Justice art. 38, Apr. 18, 1946.

ii More precisely, because we view the distinction between mandatory and default rules as a continuum rather than a binary, we would place the doctrine of absolute immunity towards the mandatory end.

iii The case even involved debt arising out of sovereign bonds, although our data will show that waivers of this sort were extraordinarily rare.

iv The authors of the Harvard Project acknowledged that their draft convention was not merely descriptive $(1932,474)$, but the authors clearly viewed the waiver rule as consistent with international custom.

${ }^{\mathrm{v}}$ Section 13(4) authorizes execution (again, subject to certain conditions) on property "in use or intended for use for commercial purposes," while section 13(3) allows "the giving of any relief or the issue of any process with the written consent of the State concerned."

${ }^{v i}$ Accounts differ as to when France adopted restrictive immunity. The Snow Report (1949) identified the date as 1929; more recent scholarship puts it at 1969 (Verdier and Voeten 2014, 12). The difference does not matter for our purposes, especially as it remained unclear whether issuing bonds was a commercial act (e.g., Badr 1984, 57-59). For convenience, we adopt 1929. 
vii The economic literature emphasizes weak legal enforcement as a central problem in the sovereign debt markets (e.g., Aguiar and Amador 2014; Panizza, et al. 2009). Yet if sovereign immunity were a default rule, creditors could have bargained for greater enforcement rights — not only the right to sue, but the right to seize assets found outside the sovereign's own borders.

viii The count excludes bonds issued by sub-sovereign entities, such as development banks and cities; bonds issued by international organizations created by treaty, such as the European Coal and Steel Community; and bonds issued in local markets, where the borrower's citizens historically comprised a much greater proportion of the investor base.

${ }^{\text {ix }}$ We counted a bond as issued in Paris if it was listed on the Paris Bourse, if coupon or principal payments were made in France, if the bond was payable in French francs, or if the bond or related sales documents were written in French. In any of these cases, it is likely that French citizens would have comprised a substantial part of the investor base.

${ }^{\mathrm{x}}$ Prospectus for the Republic of Finland, \$50,000,000 8.75\% Bonds Due 1992 (Oct. 19, 1977).

${ }^{\mathrm{xi}}$ For example: "To the extent that the Republic may in any jurisdiction claim for itself or its assets or its revenues immunity from suit, execution, attachment... the Republic agrees not to claim and irrevocably waives such 
immunity to the fullest extent permitted by the laws of such jurisdiction" (Republic of Hungary, Offering Circular for 4.5\% Notes due 2013, p. 11). xii The figure reports the data by issue rather than by issuer; thus, certain countries are over-represented. But reporting the data by issuer does not alter the findings.

xiii The first draft of the legislation that became the FSIA was introduced with the joint support of the Department of State and the Department of Justice in January 1973.

${ }^{\text {xiv }}$ To our knowledge, these direct loan contracts are not available to researchers. We have tried to track them down and have failed. Because they were private documents, they also would not have been available to Delaume, although he may have obtained some through informal channels.

${ }^{\mathrm{xv}}$ Lawyers familiar with sovereign debt practices in the 1970s corroborate Delaume's claims in that decade (Wood 2010, 14). For prior decades, however, we are skeptical. Our data often contradict Delaume's assertions about "routine" practice. For example, Delaume asserted that, by the 1960s, sovereign bonds issued in continental Europe routinely included immunity waivers $(1967,174)$. Although we do not have a large sample of such bonds, those we do have mirror bonds issued in New York and London. For example, bonds listed on the Frankfurt exchange in 1968 by South Africa do not include a waiver of sovereign immunity, nor do Liberian bonds issued in Paris in 1963. And we have dozens of 
bonds issued in European markets between 1900-1950, none of which includes a clause submitting to the jurisdiction of foreign courts.

${ }^{\text {xvi }}$ The arbitration clauses appear in the so-called League Loans- postWWI reconstruction loans arranged under the auspices of the League of Nations (e.g., Myers 1945) - or in loans based on that contract template.

${ }^{\text {xvii }}$ Historically, creditor countries have been ambivalent about protecting their citizens' investments in foreign government bonds (e.g., Lipson 1985). Yet when consistent with broader geopolitical interests, governments have played a much more active role, as with U.S. "dollar diplomacy" in Latin America in the first decades of the twentieth-century (e.g., Rosenberg 1999; Maurer 2013).

xviii In earlier work, we found that over 40 percent of bonds issued before World War II included such revenue "earmarks" (e.g., Weidemaier, Scott, and Gulati 2013).

${ }^{\text {xix }}$ Whytock and Chilton (2015) present evidence that the FSIA may have exacerbated this dynamic by transferring immunity determinations to the courts, although they agree that the Department "was perceived to be politicized and inconsistent” (p. 427).

${ }^{\mathrm{xx}}$ Société NML Capital Ltd. v. Republique Argentine, Cour de Cassation (1ère Chambre Civile), No. 09-72.057 (Sept. 28, 2011); Société NML Capital (Iles Caïmans) v. Etat d'Argentine, Cour de Cassation (1ère Chambre Civile), No. 10-25.938, 11-10.450 and 11-13.323 (Mar. 28, 2013)). The waiver provides that 
"[t]o the extent the Republic or any of its [assets] ... shall be entitled, in any jurisdiction ... to any immunity ... from execution ... the Republic ... has irrevocably waived such immunity to the fullest extent permitted by the laws of such jurisdiction." (Form of Security attached to 1994 Fiscal Agency Agreement, p. A-17). In a recent case, another French court appears to have allowed seizure notwithstanding the lack of an express reference to diplomatic assets.

${ }^{x x i}$ Our data are also consistent with the view (e.g., Coyle 2015) that U.S. courts are more willing to embrace principles of international law when incorporated into domestic statutes. For the reasons discussed in the text, we are skeptical that there was a general practice among states of enforcing waivers of sovereign immunity. Yet even if there had been such a practice, statutory enactment might have been necessary to prompt U.S. courts to embrace the rule. xxii The FSIA left unclear whether the issuance of debt was a commercial act for which a sovereign lost jurisdictional immunity, but the legislative history implied that the answer was "yes" (Weidemaier 2014).

${ }^{x x i i i}$ For example, the FSIA's default rule denies execution immunity only for assets "used for a commercial activity" in the U.S. and "used for the commercial activity upon which the claim is based" (28 U.S.C. § 1610). This latter ("nexus") requirement dramatically limits a creditor's right to execute a judgment. But the nexus requirement disappears if the sovereign has waived execution immunity. 
xxiv The inability to opt out of CIL rules is subject to criticism, especially as treaties often provide unilateral opt out rights (Bradley and Gulati 2010). 